тематичних виставок-консультацій, конференцій з обміну досвідом родинного виховання. Ведення журналів запитань та відповідей допомагає встановити тісний зворотний зв'язок. Усі означені форми роботи між членами родин та педагогами покликані активізувати педагогічне навчання, загальна мета якого - підвищити педагогічну і психологічну освіту дорослих, сприяти грамотному застосуванню ними знань у царині сімейного виховання.

Отже, формування педагогічної культури батьків розпочинається з усвідомлення ними можливостей i потреб особистого внутрішнього вдосконалення. Це постійний процес свідомого саморозвитку дорослих, що потребує використання цілісної педагогічної системи як певної сукупності взаємопов'язаних засобів і методів, необхідних для забезпечення організованого, цілеспрямованого й прогнозованого впливу на формування особистості із заданими якостями. Усі форми педагогічної роботи з батьками, що проводяться в дошкільному навчальному закладі повинні: враховувати право батьків на власну думку, позицію, систему цінностей; інформувати їх не лише про обов'язки, але й про права, якими вони можуть скористатись; позитивно ставитись до виявів батьківської ініціативи і творчості.

\title{
Література
}

1. Алексєєно Т. Формування педагогічної культури сучасної молодої сім’ї Т. Алексеєнко // Рідна школа. - 1998. - № 1 - 2. - С. 46-47. 2. Долинна О. Батьки в дошкільному закладі: споживачі та гості чи партнери-однодумці? / О. Долинна, О. Низковська // Дошкільне виховання. 2007. - № 1. - С. 6-8. 3. Кирієнко Т. Співпраця з родиною. Семінар для педагогів / Т. Кірієнко // Дошкільне виховання. - 2006. - № 10. - С. 7-9. 4. Назаренко А. Сім’я і дошкільний заклад / А. Назаренко // Дошкільне виховання - 1995. - № 8. - С. 11. 5. Островська Л. Ф. Сімейне виховання дошкільника / Л. Ф. Островська. - К., 1977. - 121 с. б. Пеньковська Н. Сім'я формує самооцінку дитини / Н. Пеньковська // Дошкільне виховання. - 2002. - № 6. - С. 16-19. 7. Постовий В. Сучасна сім’я і їі педагогіка / В. Постовий. - К., 1994. - 224 с. 8. Свирська Л. Взаємодія дорослих із дітьми раннього віку / Л. Свирська, Н. Петрова. - К., 2004. - 112 с. 9. Спиваковская А. С. Как быть родителями / А. С. Спиваковская. - М., 1986. - 332 с. 10. Спичак М. Курс на співпрацю з батьками / М. Спичак // Дошкільне виховання. - 2007. - № 3. - С. 14. 11. Сухарева Л. С. Піклуємось разом. Робота з батьками дошкільників / Л. С. Сухарева. Х. : Основа : Тріада, 2008. - 128 с. 12. Терещенко О. Родинні збори в дитячому садку / О. Терещенко // Дошкільне виховання. - 2007. - № 2. - С. 18-20. 13. Тоцька Т. Виховувати серцем / Т. Тоцька // Дошкільне виховання. - 2007. - № 3. - С. 14-17. 14. Федорович Л. Дидактичні принципи моделювання взаємодії сім'ї, дошкільної установи, школи / Л. Федорович // Рідна школа. - 1999. - № 9. - С. 65-68. 15. Хромова О. Л. Педагогічний всеобуч батьків /О. Л. Хромова, Т. В. Кравченко. - К. : Знання, 1990. - 32 с.

\section{МОВНА СИТУАЦІЯ ПІВДЕННО-СХІДНОГО РЕГІОНУ І ВРАХУВАННЯ ЇЇ ВПЛИВУ НА ПРОЦЕС НАВЧАННЯ ДОШКІЛЬНИКІВ УКРАЇНСЬКОЇ МОВИ}

Казанцева Л. І. Мовна ситуація південно-східного регіону і врахування ії впливу на процес навчання дошкільників української мови.

У статті визначено особливості стану мовної ситуації південно-східного регіону України, надано характеристику соціомовленнєвого середовища як чинника формування мовної особистості дитини-дошкільника.

Ключові слова: мовна ситуація, соціомовленнєве середовище, двомовність, рідна мова, домінантна мова, україномовний, російськомовний.

Казанцева Л. И. Языковая ситуация юго-восточного региона и учет её влияния на процесс обучения дошкольников украинсконскому языку. 
В статье определены особенности состояния языковой ситуации юго-восточного региона Украины, дается характеристика социально-речевой среды как фактора формирования языковой личности ребенка-дошкольника.

Ключевые слова: языковая ситуация, социально-речевая среда, двуязычие, родной язык, доминантный язык, русскоязычный, украиноязычный.

Kazantseva L. I. Linguistic situation of the south-east region and taking into consideration it's influence on to the process of education of preschool children of the Ukrainian language.

Peculiarities of the linguistic situation of the south-east region of Ukraine are determined, the characteristics of the sociolinguistic environment as a factor of the formation of a preschool child's personality are given.

Key woods: linguistic situation, sociolinguistic environment, bilingualism, vernacular, dominant language, Ukrainian-speaking, Russian-speaking.

Навчання дошкільників української мови вимагає урахування характеру лінгвосоціуму, оскільки діти від народження стихійно засвоюють мову (мови) того природного середовища, в якому постійно перебувають. Від впливу різних мовних утворень, їх співвідношення за домінацією, за функціонально-аксіологічним розподілом залежить вектор мовленнєвого розвитку дитини. Канали впливу мовних утворень мають ураховуватися під час вибору моделі навчання дошкільників української мови як рідної, а отже, домінантної, та як державної, тобто другої й комунікативно вторинної мови. Отже, навчання української мови не може бути тотожним для дітей, які перебувають у різних соціомовленнєвих середовищах. Оптимізація навчання української мови потребує вивчення характеру середовища 3 притаманною йому мовною ситуацією для вибору такого способу засвоєння мови, який максимально враховує вихідний мовленнєвий рівень дітей і вплив лінгвосоціуму. Тому метою статті є визначення мовної ситуації південносхідного регіону і врахування ії впливу на процес навчання дошкільників української мови

У південно-східному регіоні України утворились складні функціональні відносини між компонентами соціально-комунікативної системи і сформувалася своєрідна мовна ситуація, яка характеризує полікультурне середовище. Важливі аспекти мовної ситуації висвітлюються в дослідженнях В. Авроріна, В. Бєлікова, Т. Воропаєвої, Г. Вусик, В. Демченка, М. Кочергана, Л. Крисіна, Л. Масенко, В. Михальченка, Л. Ставицької, Г. Степанова, О. Тараненка, Е. Туманяна, В. Хмелька, Н. Шумарової та ін. У їхній інтерпретації, мовна ситуація - це «сукупність форм існування однієї мови або їх сукупностей у територіально-соціальному взаємовідношенні і функціональній взаємодії в межах певних географічних регіонів або адміністративно-політичних утворень» [3, с. 126].

Мовну ситуацію полімовного соціуму формують насамперед мовні утворення, які використовуються у процесі спілкування між етносами або їх частинами. Мовні утворення, що функціонують усередині етносу, в більшості випадків теж диференціюються за соціально-функціональною ознакою. Внутрішньоетнічні контакти здійснюються здебільшого за допомогою не одного, а декількох мовних утворень (літературної мови, діалектів, койне). Мови етносів можуть виходити за межі етнічного спілкування, i виконувати функцію міжетнічного спілкування. Від престижності, розповсюдженості і функціональності всередині етносу залежить не лише вихід мовного утворення за етнічні рамки, а й подальша перспектива його розвитку. Під час поширення мови за межі етносу змінюється і її статус: мова з компонента етнолінгвістичної ситуації перетворюється на компонент мовної ситуації країни чи регіону (Т. Воропаєва, Ю. Жлуктенко, М. Кочерган).

У сучасному мовознавстві існує традиція опису мовної ситуації за допомогою кількісних, якісних та оцінних критеріїв (Р. Белл, У. Брайт, Г. Вусик, Л. Масенко, Л. Нікольський, О. Швейцер). До кількісних критеріїв відносять: 1) кількість ідіомів у цій мовній ситуації; 2) демографічну потужність ідіомів, тобто кількість мовців, які володіють 
кожним ідіомом у співвідношенні до загальної кількості населення ареалу, що досліджується; 3) комунікативну потужність ідіомів, тобто кількість комунікативних сфер, які обслуговує кожна з мов; 4) кількість домінувальних ідіомів.

За кількістю ідіомів у складі мовної ситуації розрізняють монокомпонентні (один ідіом), та полікомпонентні (декілька ідіомів). За параметрами демографічних та комунікативних потужностей виокремлюють збалансовані - незбалансовані, або їх називають рівноважні та нерівноважні ситуації, які, у свою чергу, поділяються на однополюсні (за умови домінування одного 3 ідіомів) та багатополюсні (за умови домінування декількох ідіомів).

Якісними критеріями визначення мовної ситуації є: 1) характер ідіомів відповідно до їх гомогенних інваріантно-варіативних або гетерогенних відношень; 2) структурногенетичні відношення між мовними системами (споріднені, неспоріднені тощо); 3) функціональна рівнозначність - нерівнозначність мов; 4) характер металекту домінувальної мови.

У багатомовних суспільствах мови переважно нерівноправні. За цією ознакою розрізняють основну або домінантну (подекуди зустрічаємо терміни «перша», «первинна») мову та додаткову (або «другу», «вторинну»).

Оцінні параметри характеризують ідіоми за їх комунікативною спроможністю, вживаністю, престижністю тощо. Оцінні характеристики відбивають суб'єктивне ставлення носіїв мови до своєї та до інших мов, надають уявлення про ціннісні орієнтації мовного колективу, уважають Т. Бурда, Т. Воропаєва, В. Демченко, Л. Масенко, Л. Ставицька, В. Хмелько, В. Чемес.

Полімовному суспільству притаманні білінгвізм і диглосія, які $є$ його провідними станами (Ю. Жлуктенко, А. Росетті, Л. Ставицька, Г. Степанов, О. Швейцер). Білінгвізм є наслідком використання індивідом або суспільством більш ніж одного мовного коду (Р. Белл, У. Вайнрайх, А. Мартіне, А. Росетті), станлвить один із випадків співіснуючих систем мов. В основі класифікації білінгвізму в індивідуальному аспекті покладаються різні ознаки: ступінь складності мовленнєвих дій, які виконуються білінгвом другою мовою, ступінь оволодіння білінгвом другої мови, час формування двомовності, засоби набуття двомовності, спосіб формування двомовності (А. Богуш, У.Вайнрайх, Є. Верещагін, Ю. Дешерієв, Ю. Жлуктенко, А. Росетті, А. Супрун, М. Успенський, Ч. Фергюсон, Е. Хауген, Л. Щерба та ін.). Науковці (Р. Белл, У. Вайнрайх, Ч. Осгуд) розглядають білінгвізм як шкалу, яка розміщується між змішаним білінгвізмом, у якому дві мови поєднуються в одну систему, і координативний білінгвізм, де дві мовні системи залишаються відмежованими, що, власне, і надає відповідь на кардинальне запитання: чи є особа одномовною, чи двомовною [1, с. 157].

У соціальному аспекті білінгвізм може бути контактним і дистантним. За умови тривалого контакту відбувається трансформація функцій першої і другої мови: засвоєна пізніше мова починає виконувати провідну соціальну функцію, а етнічна мова припиняє виконувати роль домінантного коду (Ю. Дешерієв, О. Щвейцер). 3 позицій кодифікації розрізняють нормативний, однобічно-нормативний і ненормативний білінгвізм. Перший тип характеризується дотриманням лінгвістичних норм обох мов; однобічно-нормативний - дотриманням норм тільки однієї із двох мов, здебільшого рідної; ненормативний користуванням другою мовою з порушенням її норми частково або в цілому.

Диглосія в лінгвістиці кваліфікується як взаємодія двох різновидностей однієї і тієї самої мови. Ч. Фергюсон під диглосією розуміє «два чи більше різновидів однієї і тієї самої мови, які використовують мовці у різних умовах», або «два різновиди мови, якими послуговуються у цьому колективі, кожен із яких відіграє визначну роль» [7, с. 3]. Найчастіше диглосію пов'язують із функціональною спеціалізацією: одночасним існуванням двох мов або двох варіантів однієї мови із функціональним їх розподілом, який зумовлюється не етномовною належністю мовців, а комунікативними ситуаціями [3, c. 179]. 
Сучасній мовній ситуації південно-східного регіону України притаманний стан білінгвізму та диглосії (В. Демченко, Л. Масенко, О. Тараненко, У. Семчук). Основну мовну пару становлять українська і російська мови. За статистичними розвідками 1989 року, носіями української мови є $44 \%$ населення, російської мови - $56 \%$, за іншими даними, російськомовних громадян нараховується приблизно «між половиною і третиною населення». Поділ населення країни за мовним принципом на «україномовне» i «російськомовне» ускладнюється тим, що воно $є$ не етнічним, а етномовним. Демографічні чинники утворили незбалансовану ситуацію - непропорційне співвідношення між культурно-етнічною і культурно-лінгвістичною ідентичністю мовців.

Дослідження останніх 15 років (Н. Шумарова, 1997 р.; В. Чемес, 2000 р.; В. Демченко, 2001 р.; Т. Бурда, 2002 р.; Ю. Саплін, 2002 р.; В. Товстенко, 2003 р.; В. Хмелько, 2004 р.; Л. Масенко, 2006 і 2010 р.p.; В. Скляр, 2007 р.) засвідчують асиметричний характер двомовності в Україні. Процеси українізації і русифікації мають виражену регіональну відмінність і відбуваються в напрямах «Захід - Схід». Так, В. Скляр фіксує в період 19892001 pp. у західному векторі скорочення на $27 \%$ осіб, які вважають російську мову рідною; у південно-східному векторі, навпаки, зростання на 33,2 \%. Отже, загальна частка українців, які вважають рідною російську мову, переважно зосереджені в південносхідному регіоні - 87,9\% по Україні. За даними Л. Масенко, рідною російську мову вважають на Сході 58,5 \% мешканців, на Півдні - 56,7 \%; українська мова $є$ рідною для 25,8 \% мешканців на Сході і 29,5\% на Півдні [4].

Ще переконливішою щодо регіональної мовної спеціалізації $є$ статистика відносно самовизначення осіб з мовою повсякденного спілкування. Тільки російською мовою на Сході і Півдні спілкуються від 43,9 до 49,0 \% осіб; переважно російською - спілкуються від 14,0 до 25,9 \% мовців; рівною мірою українською і російською - від 17,1 до 21,6 \%; у більшості ситуацій українською - від 10,2 до 3,7 \%; і лише 6,3 \% мешканців Півдня і 1,5 \% мешканців Сходу спілкуються завжди українською мовою [4, с. 111].

У дослідженнях зазначено факт зменшення україномовного родинного спілкування від старшого до молодшого покоління з регіональною відмінністю. Найбільш інтенсивно ці процеси відбуваються в південно-східному регіоні. На Півдні вікові показники збільшення русофонів репрезентуються так: 56,1 \% мовців старшого покоління; 58,0 \% - середнього покоління; 64,6\% - молоді. На Сході показники вживання російської мови у трьох поколіннях такі: 50,7 \%, 61,4 \% і 73,5 \% [4, с. 113]. Отже, фіксується зростання потужності російської мови через етап двомовного спілкування середнього покоління.

Українська мова поступається російській за показником комунікативної потужності. Дослідники (В. Гак, Р. Кісь, Л. Масенко, У. Семчук, Л. Ставицька) уважають, що становлення і послідовний розвиток мови забезпечується піi використанням у трьох галузях: у побуті, освіті та суспільному житті. Мова відмирає, якщо вона перестає бути засобом спілкування в родині. Вона біднішає й не розвивається, якщо не використовується як мова викладання в школі і спілкуванні. Відносно української мови слід зазначити, що внаслідок попередніх асиміляційних процесів вона стала менш уживаною в сімейному спілкуванні, на виробництві, побуті, у сфері державного управління. Ще менш помітну роль у мовному житті регіону відіграють етноменшинні мови. 3 рисами діалекту, вони використовуються на рівні родинного спілкування та в побутовій комунікації етнічних сел. Отже, за сферами функціонування російської, української та етнічних мов ситуацію можна вважати диспропорційною.

Дослідники соціолінгвістичної ситуації в Україні (В. Демченко, Р. Кісь, Л. Масенко, Ю. Саплін, О. Тараненко та ін.) зазначають, що російська мова здобула демографічні переваги в містах, що вказує на низький статус української мови серед міського населення. Звучання російської мови визначає мовний портрет більшості українських міст Півдня і Сходу. Між українокультурною традицією села і русифікованою культурою міста утворилася значна психокультурна дистанція. Не може бути популярною поміж мовців та мова, яка не підкріплена потужним потенціалом сучасної урбаністичної культури, 
зауважують науковці [2; 4]. Отже, незбалансована, гіперглосна мовна ситуація в південносхідному регіоні зумовлюється не так часткою етнічних росіян (від 21,9\% до $39 \%$ ) i навіть не часткою українців, що вважають російську мову першою (10,2\%), а функціональним домінуванням російської мови в українських містах, пов'язаним із процесами урбанізації.

Специфічною рисою мовної ситуації є поширення практично на всій території країни змішаних українсько-російських мовленнєвих утворень, що виникають унаслідок хаотичного змішування елементів української та російської мовних систем. До лінгвістики це явище увійшло під назвою «суржик». О. Тараненко визначає суржик як «структурно-функціональний компонент українського просторіччя з помітною домішкою русизмів, що став розмовною мовою і фактично основним засобом спілкування більшості україномовного населення країни внаслідок масової тривалої контактної україноросійської двомовності в іiї асиметричній (диглосній) формі» [5, с. 665].

Нині майже повсюдно на території Півдня та Сходу України, серед усіх соціальних груп домінує мовне утворення змішаного типу з російською основою. Р. Кісь уважає, що в містах процеси злиття двох мов у славнозвісний «суржик» посилюються, «це не тільки інтерференція різних картин світу, різних нормативних цінностей, різних етнолінгвістичних систем» - це утворення креалізованої мови [2, с.9]. У зв'язку 3 широким розповсюдженням суржику науковці (М. Жуйкова, Л. Масенко, В. Хмелько) вбачають небезпечну тенденцію для функціонування української мови. Використання суміші української і російської мов зафіксоване серед $14 \%$ етнічних українців, тоді як серед росіян носії суржику становлять лише $5 \%$, а серед представників інших етнічних груп - від 5 до $10 \%$. Змішана субмова для значного числа україномовних носіїв $\epsilon$ проміжною фазою до переходу на російськомовний код спілкування. Перехід суржикомовних груп до російськомовних підтверджують дані досліджень В. Хмелька. Так, у цілому в Україні, кількість користувачів російської мови з 2000 року до 2003 зросла на 3,4 \% за рахунок суржикомовного населення.

За особливостями контактування компонентів білінгвізму в регіоні 3 позицій соціолінгвістики можна визначити декілька типів білінгвізму. За кількістю тих, хто володіє більше, ніж одним мовним кодом, білінгвізм є підстави вважати масовим. За рівнем мовної компетенції білінгвізм здебільшого є однобічно-нормативним 3 порушеннями української літературної норми, з помітним інтерферентним впливом російської мови. За характером використання контактуючих мов двомовність $є$ частковою, оскільки більшість мовців регіону виявляють вміння користуватися другою мовою лише в окремих ситуаціях спілкування. Дослідження фіксують низький ступінь зацікавленості носіїв російської мови в активному володінні мовою корінної національності, тому вчені схильні вважати російськонаціональний різновид двомовності пасивним, на відміну від національно-російського (В. Демченко, У. Семчук). Двомовність також можна вважати однобічною, оскільки лише $3,9 \%$ етнічних росіян готові спілкуватися 3 україномовними особами їхньою етнічною мовою.

Варто, надаючи характеристику мовній ситуації, підкреслити відзначити, що функцію коду міжнаціонального спілкування виконує російська мова, а не українська, що було б закономірним для державної мови. Згідно $з$ переписом 2001 р. рідною російську мову назвали 88,5 \% греків, 83, \% євреїв, 64,7 \% німців, 62,5 \% білорусів, 58,7 \% татар, 54,4 \% грузинів, $43 \%$ вірмен, 30,3\% болгар.

Мовну ситуацію за кількісною параметрією можна визначити як полікомпонентну, що нараховує більше 10 мов, нерівноважну багатополюсну, оскільки домінують дві етнічні мови - російська й українська. Демографічна потужність мов етнічних меншин становить непропорційно малий відсоток по відношенню до домінантних мов - всього $3,8 \%$. Дослідження вказують на те, що більшість етнічних мов не функціональні з різних причин: етнофони мають дисперсне розселення і не утворюють достатньої маси для запровадження етномовних закладів освіти; для носіїв етнокультури етнічна мова в прагматичному плані 
виконує роль первинної, прокладаючи шлях до значно більш престижних і комунікативно значущих мов; етнічні мови виконують функцію засобу спілкування в колі етнічного осередку.

Формування мовленнєвої особистості дитини-дошкільника в полікультурному середовищі південно-східної України має містити специфіку, спричинену низкою соціокультурних і соціомовленнєвих відмінностей середовища. Як відомо, дитина у процесі свого розвитку не може не взаємодіяти з довкіллям - 3 цієї взаємодії складається механізм розвитку. Перебуваючи і взаємодіючи із середовищем 3 певними характеристиками, розвиток дитини набуває відповідних рис і ознак. Якщо середовище складне, неоднорідне, багатополюсне, то його вплив може мати неоднозначні наслідки.

3 метою дослідження стану навчання дітей української мови в умовах дошкільних закладів ми здійснили спробу вивчити характер соціомовленнєвого середовища, в якому дітьми стихійно засвоюються мови через наслідування. Задля цього анкетувалися ті, від кого дітьми переймаються зразки мовлення - батьки дітей дошкільного віку та вихователі ДНЗ, на предмет з'ясування їхньої етнічної і рідномовної ідентифікації, вибору комунікативно першої мови, а також визначення домінантної мови діяльності дошкільних закладів у співвідношенні до їх мовного статусу. В анкетуванні взяли участь 7000 батьків дітей-дошкільників та близько 2000 вихователів, які мешкають в містах Запоріжжя, Бердянськ та Приморськ Запорізької області; Донецьк, Маріуполь Донецької області; Дніпропетровськ, Жовті Води Дніпропетровської області.

Результати дослідження виявили поліетнічний склад батьків дітей дошкільного віку, які мешкають у південно-східному регіоні. Переважну кількість становили етнічні українці й етнічні росіяни в пропорції 52,5 до 43. Представництво етнічних груп серед батьків визначене як нечисленне (4,5\%) проте різноманітне - в анкетах зафіксована приналежність до 9 етнічних груп. Найбільшу групу в загальному складі досліджуваних становили болгари $-3 \%$.

Визначення батьками-респондентами мов у статусі рідної не відповідає їхній етнічній ідентифікації. Найсуттєвіші розбіжності за цим параметром показали етнічні українці тільки 34,5 \% батьків-українців назвали рідною мовою українську. Найвищу етномовну стійкість демонстрували росіяни - в 98 \% вважали свою етнічну мову рідною. Не суттєво нижчими виявилися показники відповідності між етнічною самоідентифікацією і самовизначенням рідної мови серед батьків, які належать до етнічних спільнот - 84 \% інформантів.

Важливим показником функціональності мови в соціолінгвістиці є розповсюдженість мови в сімейному спілкуванні. Результати анкетування, на жаль, показали невисоку вживаність української мови в родинах. Для переважної більшості батьків-мешканців міст південно-східного регіону мовою родинного спілкування є російська мова. На це вказали відповіді 87 \% українців, 36 \% представників етноспільнот і 98,8 \% росіян.

Незначний відсоток батьків дітей-дошкільників указують на свою двомовність. Найвищою вона $\epsilon$ в українців - $12 \%$ мовців постійно послуговуються українською і російською мовами. Особливість їхньої двомовності полягає у функціональній спеціалізації щодо сфер застосування двох мов. Фактично лише 3,5 \% з них не відчувають різниці у виборі мов для різних ситуацій комунікації, а отже, засвідчують координативну двомовність.

Опрацювання результатів анкетування батьків дітей-дошкільників на матеріалі репрезентативної вибірки надає змогу констатувати деякі узагальнення. Переважно російськомовний тип спілкування в усіх суспільних і приватних сферах комунікацій мешканців міст південно-східного регіону країни не сприяє формуванню україномовного комунікативного простору. Історично сформований у регіоні тип міжмовної взаємодії залишається в контексті україно-російської двомовності. У цій парі російська мова виборює собі статус мови-переможниці, оскільки для переважної більшості мешканців регіону вона 
залишається функціонально першою мовою, а також є провідним засобом міжнаціональних контактів у всіх суспільних сферах комунікації.

Беручи до уваги, що в мовному контакті перебувають не дві мови, а три і більше, визначимо співвідношення мов за домінацією. У соціолінгвістиці домінація визначається передусім тим, наскільки важливі і як багато сфер спілкування обслуговує мова. Дослідивши пріоритети щодо мовного вибору в різних ситуаціях спілкування етнічних українців і представників національних меншин, які володіють своєю етнічною мовою, можна визначити залежність: носії етнічних мов, як і українці, у своїй мовленнєвій поведінці орієнтуються на російську, а не на українську мову.

Визначена мовна ситуація може піддаватися аналізу як чинник формування двомовності в дошкільників південно-східного регіону. По-перше, від народження на становлення мовленнєвої поведінки дітей впливають декілька мов, найчастіше, це літературна та розмовна російська, літературна українська мова, яка сприймається через телебачення, та «суржик». У сім'ях етнічних меншин до цього коктейлю додається розмовний стиль етнічної мови. Подібний невпорядкований вплив на дитину 3 несформованим «мовним імунітетом» кількох мов сприяє розвитку «змішаної» двомовності. По-друге, панування російської мови в більшості сімей створює об'єктивні перешкоди для розвитку національно-української двомовності. Сім'ї росіян, етнічних українців, національних меншин регіону, а також змішані сім'ї здебільшого російськомовні, оскільки російська мова передусім в побутовій і приватній комунікаціях посідає вищий статус престижності порівняно 3 українською. Результати опитування дозволили виокремити кілька причин орієнтації білінгвів і триглотів на російську мову як домінантну: 1) домінантним $\epsilon$ російськомовне оточення; 2) відсутня україномовна практика; 3) ця мова засвоєна 3 дитинства. Отже, дошкільники здебільшого позбавлені можливості чути українську мову і практикуватися в мовленні в колі сім'ї та найближчому оточенні.

Важливим аспектом дослідження було визначення реальної ситуації відносно застосування мов у діяльності дошкільних закладів південно-східного регіону. Групи педагогів російськомовних і україномовних ДНЗ зазначили співвідносні дані щодо функціональності двох мов, хоча мали б суттєво відрізнятися. Так, вихователі дошкільних закладів 3 російською мовою навчання вказали, що 3 них 71 \% всю освітню діяльність здійснюють російською мовою і лише окремі заняття, свята, розваги проводять українською мовою; $18 \%$ здійснюють освітню діяльність двома мовами, решта - $11 \%$ вживають виключно російську мову.

Вихователі ДНЗ з україномовним статусом у відповідях анкети сумарно вказали, що $13 \% 3$ них працюють виключно російською мовою; 9\% - російською проводять окремі освітні заходи; $26 \%$ уживають дві мови, не роз'яснюючи порядок розподілу мов, що надає підстави думати про їх безсистемне вживання, а можливо навіть змішування; $38 \%$ вихователів указують на функціональну диференціацію мов: українською мовою проводяться заняття і масові заходи, а російською спілкування в повсякденні, що підтверджує домінацію російської мови; і лише $14 \%$ педагогів визначили свою однозначну прихильність українській мові. Отримана інформація надає підстави вважати, що діти перебувають в україномовних закладах фактично під впливом російської мови.

Важливим показником якості освітнього процесу в питанні навчання української мови $\epsilon$ рівень володіння педагогами українським мовленням. Шляхом анкетування вивчалася самооцінка вихователів відносно рівня володіння державною мовою. Для аналізу результатів самооцінки враховувалась інформація про мовний статус ДНЗ. Анкетування показало, що в україномовних закладах $24 \%$ вихователів оцінили рівень володіння українською мовою як високий, $63 \%$ зазначили його як середній, а $13 \%$ визнали рівень володіння низьким. Вихователі російськомовних дошкільних закладів свій рівень володіння українською мовою визначили так: високий рівень притаманний $6 \%$ фахівців, середній рівень $-78 \%$, низький рівень $-16 \%$. 
Порівняння результатів самооцінки вихователів та їхніх відповідей на запитання про мову спілкування в різних комунікативних сферах свідчить про завищену самооцінку інформантів. Проаналізуємо: тільки 10,8 \% опитаних педагогів мають україномовну практику спілкування поза дошкільним закладом, але при цьому вказують на високий рівень володіння мовою $30 \%$ вихователів; 63\% фахівців україномовних закладів і $78 \%$ російськомовних оцінюють свій рівень навичок україномовлення як середній, хоча вказують на повну відсутність практики спілкування українською мовою поза ДНЗ. Зауважимо, спеціальні спостереження та наукові джерела засвідчують необхідність більш або менш постійної мовленнєвої практики як умови володіння мовою.

Отже, результати дослідження виявили в цілому несприятливі умови для опанування дітьми дошкільного віку української мови в стихійному соціомовленнєвому середовищі південно-східного регіону країни. У родинній та побутовій комунікації діти не мають можливості шляхом наслідування засвоювати українську мову, оскільки контактують переважно 3 російськомовним оточенням. Незадовільною для засвоєння дітьми української мови виявилася організація мовного режиму в дошкільних навчальних закладах південно-східного регіону як з україномовним, так і російськомовним статусом.

\section{Література}

1. Белл Р.Социолингвистика: цели, методы и прийомы : [моногрофия] / Р. Г. Белл. - М.: Международные отношения, 1980. - 318 с. 2. Кісь Р. Етнічна маргінальність і мовлення (про деякі аспекти етнолінгвістичної ситуації в містах України / Р. Кісь // Урок української. - 1999. - № 2-3. - С. 6-12. 3. Кочерган М. П. Загальне мовознавство: [підручник] / М. П. Кочерган. - К. : Видав. центр «Академія», 1998. - 288 с. 4. Масенко Л. Нариси з соціолінгвістики: [монографія] / Л. Масенко. - К. : Видав. дім «Києво-Могилянська академія», 2010. - 243 с. 5. Українська мова. Енциклопедія ; ред. кол.: В. М. Русанівський та ін. - 2-е вид., випр. і доп. - К. : Укр. енциклопедія, 2000. - 752 с. 6. Швейцер А. Д. Введение в социолингвистику : [учеб. пособ]. / А. Д. Швейцер, Л. Б. Никольский. - М. : Высшая школа, 1978. - 216 с. 7. Ferguson С. К. A. Diglossia. - Word, 1962. - vol. 15. - № 2. - P. 3-11.

УДК [371:811.161.2](477.75)

Ю К. Картава, ст. викладач, Євпаторійський інститут сочіальних наук РВНЗ «Кримський гуманітарний університет» (м. Ялта)

\section{СТАН ВИКЛАДАННЯ УКРАЇНСЬКОЇ МОВИ В ЗАКЛАДАХ ОСВІТИ АВТОНОМНОЇ РЕСПУБЛІКИ КРИМ}

\footnotetext{
Картава Ю. К. Стан викладання української мови в закладах освіти Автономної Республіки Крим

У статті висвітлено сучасний стан викладання української мови в загальноосвітніх закладах АР Крим, проаналізовано нормативну базу і з'ясовано основні тенденції щодо підвищення рівня викладання української мови вчителями-філологами.

Ключові слова: викладання української мови, загальноосвітні заклади, підвищення рівня викладання, учитель-філолог.
}

Картавая Ю. К. Состояние преподавания украинского языка в учреждениях образования Автономной Республики Крым.

В статье рассматривается современное состояние преподавания украинского языка в общеобразовательных учреждениях АР Крым, анализируется нормативная база и выделяются основные тенденции повышения уровня преподавания украинского языка учителями-филологами.

Ключевые слова: преподавание украинского языка, общеобразовательные учреждения, повышение уровня преподавания, учитель-филолог.

Kartavaya Y. K. Condition of teaching the Ukrainian language in secondary schools of the Crimean Autonomous Republic. 